\title{
Identifying drought events in sugarcane using drought indices derived from Modis sensor
}

\author{
Michelle Cristina Araujo Picoli(1), Daniel Garbellini Duft ${ }^{(2)}$ and Pedro Gerber Machado(3)
}

\begin{abstract}
(1)Universidade Estadual de Campinas, Faculdade de Engenharia Agrícola, Caixa Postal 6011, CEP 13083-875 Campinas, SP, Brazil. E-mail: michelle.picoli@feagri.unicamp.br (2)Laboratório Nacional de Ciência e Tecnologia do Bioetanol, Caixa Postal 6192, CEP 13083-970 Campinas, SP, Brazil. E-mail: daniel.duft@bioetanol.org.br ${ }^{(3)}$ Universidade Estadual de Campinas, Faculdade de Engenharia Mecânica, Caixa Postal 6122, CEP 13083-970 Campinas, SP, Brazil. E-mail: pedrog87@fem.unicamp.br
\end{abstract}

\begin{abstract}
The objective of this work was to evaluate the potential of several spectral indices, calculated using moderate resolution imaging spectroradiometer (Modis) images, in identifying drought events in sugarcane (Saccharum officinarum) crops. Images of Terra and Aqua satellites were used to calculate the spectral indices, using visible (red), near infrared, and shortwave infrared bands, and eight indices were selected: NDVI, EVI2, GVMI, NDI6, NDI7, NDWI, SRWI, and MSI. The indices were calculated using images between October and April of the crop years 2007/08, 2008/09, 2009/10, and 2013/14. These indices were then correlated with the standardized precipitation-evapotranspiration index (SPEI), calculated for 1, 3, and 6 months. Four of them had significant correlations with SPEI: GVMI, MSI, NDI7, and NDWI. Spectral indices from Modis sensor on board the Aqua satellite (MYD) were more suited for drought detection, and March provided the most relevant indices for that purpose. Drought indices calculated from Modis sensor data are effective for detecting sugarcane drought events, besides being able to indicate seasonal fluctuations.
\end{abstract}

Index terms: Saccharum officinarum, drought stress, image processing, satellite imagery, SPEI, warning systems.

\section{Identificação de eventos de seca em cana-de-açúcar com base em índices de seca derivados do sensor Modis}

\begin{abstract}
Resumo - O objetivo deste trabalho foi avaliar o potencial de diversos índices, calculados com o uso de imagens do sensor Modis ("moderate resolution imaging spectroradiometer"), em identificar eventos de seca na cana-de-açúcar (Saccharum officinarum). As imagens dos satélites Terra e Aqua foram utilizadas para calcular os índices espectrais, com bandas na região do visível (vermelho), infravermelho próximo e infravermelho médio, e oito índices foram selecionados: NDVI, EVI2, GVMI, NDI6, NDI7, NDWI, SRWI e MSI. Os índices foram calculados com base em imagens de outubro a abril de quatro anos agrícolas: 2007/08, 2008/09, 2009/10 e 2013/14. Esses índices foram correlacionados com o índice de seca meteorológica SPEI, calculado para 1, 3 e 6 meses. Quatro deles tiveram correlação significativa com o índice SPEI: GVMI, MSI, NDI7 e NDWI. Os índices espectrais derivados do sensor Modis a bordo do satélite Aqua (MYD) são mais adequados para o reconhecimento de eventos de seca, e março proporcionou os índices mais relevantes para esse propósito. Índices de seca calculados com base em dados Modis são efetivos em detectar eventos de seca em cana-de-açúcar, além de serem capazes de apontar flutuações sazonais.
\end{abstract}

Termos de indexação: Saccharum officinarum, stress hídrico, processamento de imagens, imagem por satélite, SPEI, sistemas de alerta.

\section{Introduction}

Some types of extreme events are more prone to occur with increasing temperature, notably heat waves and heavy rainfall (Coumou \& Rahmstorf, 2012). Drought is the most expensive natural event, and it can lead to water and food crises (Hao et al., 2014). In 2014, weather disasters (droughts and forest fires) have caused losses of US\$11.3 billion, which represented an increase of $48.8 \%$ in the average damage occurred between 2004 and 2013 (Guha-Sapir et al., 2015). Damage caused by droughts and forest fires grew from $4.7 \%$, in the $2004-2013$ period, to $11.4 \%$ in 2014 . The 2014-drought in Brazil afflicted 27 million victims, and it was the fourth drought event with greatest human impact since 2004, with damages amounting up to US\$ 5 billion (Guha-Sapir et al., 2015). 
According to Pachauri \& Meyer (2014), warm daytime temperatures will become more frequent and have greater magnitude, favoring the occurrence of drought events. In this sense, understanding and quantifying the impacts of these events on agriculture is very important. Therefore, indices based on climatic and meteorological observations have been created for this purpose, such as the palmer drought severity index (PDSI), crop moisture index (CMI), surface water supply index (SWI), and standardized precipitation index (SPI).

Vicente-Serrano et al. (2010) described a multiscale drought index - the standardized precipitationevapotranspiration index (SPEI) -, which uses precipitation and temperature data alone. It is simply based on a normalization of data from the water balance obtained with the Thornthwaite method. Few differences exist between the SPEI and the selfcalibrated palmer drought severity index (sc-PDSI) and the standardized precipitation index (SPI) (Zhao et al., 2015; Chen et al., 2016; Le et al., 2016; Wang et al., 2016). However, divergence was observed in the indices when a progressive temperature increase of 2 to $4^{\circ} \mathrm{C}$ was added to the historical series used to simulate climate change.

Among the tools developed in recent decades, remote sensing has proven to be very promising to improve the calculation and monitoring of drought events. Vegetation indices and drought, humidity, and surface temperature data derived from satellite images are used to this end (Ghulam et al., 2007). Gu et al. (2007) reported significant correlations between normalized difference vegetation index (NDVI), obtained from Modis images, calculated every 16 days, and drought. Tadesse et al. (2005) showed that when using NDVI, despite it is an effective indicator of humidity and vegetation conditions, there is a lag between the occurrence of drought event and the change in its values, which indicates that this index is not appropriate to monitor drought conditions of crops, in real time conditions.

Despite the existence of some drought identification indices, there is still no drought monitoring system for sugarcane. This represents a setback, because global climate change is affecting this crop, which is planted in over 10 million hectares only in Brazil, according to Brazilian Sugarcane Industry Association (Unica,
2015). Sugarcane products represented $43.5 \%$ of renewable source for the Brazilian energy matrix, in 2014 , and water availability is one of the main factors influencing their production.

To this end, the spectral indices were correlated with the meteorological drought index, the SPEI. This study, besides helping in the understanding of the use of remote sensing images for identifying drought events, provides a tool for quantifying the losses due to drought in Brazil, which can generate crop alerts. If the effectiveness of these indices is confirmed with sugarcane drought monitoring, it will be possible to create a warning system using such indices and other meteorological variables.

The objective of this work was to evaluate the potential of several spectral indices, calculated using moderate resolution imaging spectroradiometer images, in identifying drought events in sugarcane crops.

\section{Material and Methods}

The studied area is located in the municipality of Descalvado, in the state of São Paulo $\left(22^{\circ} 03^{\prime} 16^{\prime \prime}\right.$ to $21^{\circ} 42^{\prime} 10^{\prime \prime} \mathrm{S}$ and $47^{\circ} 47^{\prime} 38^{\prime \prime}$ to $47^{\circ} 30^{\prime} 33^{\prime \prime} \mathrm{W}$ ) - that state is one of the largest producers of sugarcane in Brazil, with a yield of 1.7 million tons of sugarcane culms in 2013 (IBGE, 2016) -, in a 20,000-ha area owned by the Usina Ipiranga. The soil in the area is predominantly Oxisol, with slopes ranging 3-9\% (declivity).

The climate is Cwa, according to the Köppen classification, indicating humid temperate climate with dry winter and hot summer. The average annual rainfall is $1,509 \mathrm{~mm}$, and the driest month is July, with $27-\mathrm{mm}$ rainfall and temperature around $18^{\circ} \mathrm{C}$, and the wettest month is January, with $273-\mathrm{mm}$ precipitation and average temperature of $24^{\circ} \mathrm{C}$ (CEPAGRI, 2016).

This study was carried out using sugarcane "pure pixels" with the same pixel size of the Modis images used $(500 \times 500 \mathrm{~m})$. All pure pixels were selected within the sugarcane plots, inside the limits of the Usina Ipiranga. A grid with the 500x500 m pixels was created from MOD09A1 (Terra) and MYD09A1 (Aqua) images, of the product Modis Terra/Aqua Surface Reflectance 8-Day L3 Global $500 \mathrm{~m}$. The 8 -day surface reflectance indicates that the best image within the 8 day-window is used. This method implies the lowest possible influence of clouds or aerosols. 
Thus, only those pixels totally inside the sugarcane areas - pure pixels of sugarcane - were selected. A total of 83 pure pixels were determined inside the mill lands. Factors such as ratoon stage, variety, and harvest time were also isolated. To homogenize the analysis, only pixels with similar characteristics were chosen. The selected sugarcane varieties have medium or late maturing cycle, in order to isolate any external factors that could affect the spectral indices.

Precipitation data from an automated weather station of the Instituto Agronômico de Campinas (IAC), located in Descalvado, were used. Monthly rainfall was compared with the historical average for this weather station. The crop seasons of 2008/09 and 2009/10 had four months with rainfall values greater than their monthly historical averages. However, the seasons 2007/08 had only two months, and 2013/14 only one month, with greater precipitation.

This study used the standardized precipitationevapotranspiration index (SPEI), developed by Vicente-Serrano et al. (2010) as an indicator that standardizes the rainfall in a given region, indicating deficits and surpluses. The SPEI uses the monthly (or weekly) difference between precipitation and potential evapotranspiration (PET). The calculation of this is similar to that of SPI, but instead it sums the climatic water balance, defined as the difference between precipitation and PET (Vicente-Serrano et al., 2010). Many authors used SPI to check meteorological drought and, thus, to check if the vegetation suffered with agricultural drought (Zhang \& Liang, 2010; Caccamo et al., 2011; Ezzine et al., 2014). These authors, therefore, present the SPI as a functional and quantitative indicator of drought, which should be analyzed in time scale. The SPI is considered to represent a drought event when it reaches the value $\leq-1$.

SPEI was estimated with periods of 1,3 (current month and the previous two), and 6 months (current and the previous five). These periods were chosen because they are suitable for agricultural drought identification (WMO, 2012). SPEIs were used in each studied month (October to April), in the crop years 2007/08, 2008/09, 2009/10, and 2013/14.

The SPEI indices were used to verify whether the influence of meteorological drought occurs instantly on sugarcane, or if it has a slow effect, as reported by Caccamo et al. (2011), using SPI indices, calculated every 6 months, correlated with drought spectral indices for forest and understory. These authors observed that the indices calculated for this period had a clearer separation between drought and non-drought periods.

SPEIs were obtained using the CRU TS3.0 dataset, at a spatial resolution of $0.5^{\circ}$. This dataset has an open source and is available on the Spanish National Research Council (CSIC) webpage, in three different formats: NetCDF, binary raster, and plain text (Vicente-Serrano et al., 2010).

Images of Terra and Aqua satellites were used due to their different times of passage. In state of São Paulo, the Terra satellite passes at about 11:00 AM (-3GMT), while Aqua passes at 1:00 PM (-3GMT) (NASA, 2015). At 1:00 PM, the temperature is higher and, therefore, the sugarcane plants have their stomata closed (Smith et al., 2005). The greater amount of sugarcane stomata open at 11:00 AM changes the plant reflectance in the infrared region.

During image acquisition, a flaw was detected in the band 5 of the product MOD09A1. This flaw is reported in Wang et al. (2011), who argued that, in some places, the use of this band (1,230-1,250 nm) may harm the results. Image processing involves their reprojection for geographic coordinates WGS84, with the software IDL 8.3. This processing is automated and also involves analysis of the band quality to discard images that are highly affected by clouds. The pixels were kept with spatial resolution of $500 \mathrm{~m}$.

The spectral indices were calculated using the red, near infrared, and shortwave infrared bands. Thus, the vegetation and the influence of climatic variables on its development were monitored. These indices are not sensitive to changes in soil (e.g., moisture) and in atmosphere, as shown by Ceccato et al. (2001). Therefore, changes in them are exclusively due to changes in plants.

The combined use of spectral bands can provide information on water content of the plant. Eight spectral indices were selected, all effective in drought identification: Hardisky et al. (1983), Hunt \& Rock (1989), Gao (1996), Zarco-Tejada \& Ustin (2001), Chuvieco et al. (2002), Ceccato et al. (2002), Gu et al. (2007), and Jiang et al. (2008). They were tested as to their ability in detecting drought in sugarcane, using

Pesq. agropec. bras., Brasília, v.52, n.11, p.1063-1071, nov. 2017 DOI: $10.1590 / \mathrm{S} 0100-204 X 2017001100012$ 
images from October to April of the crop years of 2007/08, 2008/09, 2009/10 and 2013/14 (Table 1).

For the calculation, an application was developed in IDL 8.3 , in order to automate the process. This application opens the images, copies the metadata, and identifies the image size, pixel size, projection and coordinate system. The indices were calculated one by one, using the reflectance images of Modis bands (Terra and Aqua satellites). Therefore, an image of each index was obtained for each date analyzed, accounting for a total of 3,440 images.

A database was organized with the values of the indices and of the bands, for each selected pure pixel. The procedure extracted the series in a chronological scale, for all indices and in every year, with further tabulation for comparisons with other data.

MOD09A1 and MYD09A1 products provide data every eight days. However, to match SPEI data scale (monthly), this study used the monthly median for each index. The median was used instead of the mean because it is not as much affected by extreme values (Oldford et al., 2006).

Table 1. Spectral indices used for drought monitoring: NDVI, Normalized Difference Vegetation Index; EVI2, Enhanced Vegetation Index; GVMI, Global Vegetation Moisture Index; NDI6 and NDI7, Normalized Difference Infrared Index; NDWI, Normalized Difference Water Index; SRWI, Simple Ratio Water Index; and MSI, Moisture Stress Index.

\begin{tabular}{lcc}
\hline Index & Equation $^{(1)}$ & Reference \\
\hline NDVI & $\frac{\text { NIR }- \text { RED }}{\text { NIR }+ \text { RED }}$ & Tucker (1979) \\
EVI2 & $2.5\left(\frac{\mathrm{NIR}-\mathrm{RED}}{\mathrm{NIR}+2.4 \mathrm{RED}+1}\right)$ & Jiang et al. (2008) \\
GVMI & $\frac{(\mathrm{NIR}+0.1)-\left(\mathrm{SWIR}_{1}+0.02\right)}{(\mathrm{NIR}+0.1)+\left(\mathrm{SWIR}_{1}+0.02\right)}$ & Ceccato et al. (2002) \\
NDI6 & $\frac{\mathrm{NIR}-\mathrm{SWIR}_{1}}{\mathrm{NIR}+\mathrm{SWIR}_{1}}$ & Hardisky et al. (1983) \\
NDI7 & $\frac{\mathrm{NIR}-\mathrm{SWIR}_{2}}{\mathrm{NIR}+\mathrm{SWIR}_{2}}$ & Chuvieco et al. (2002) \\
NDWI & $\frac{\mathrm{NIR}-\mathrm{SWIR}_{\mathrm{NIR}}}{\mathrm{NIRWIR}}$ & Gao (1996) \\
SRWI & $\frac{\mathrm{NIR}}{\mathrm{SWIR}^{2}}$ & Zarco-Tejada \& Ustin (2001) \\
MSI & $\frac{\mathrm{NIR}}{\mathrm{SWIR}_{2}}$ & Hunt \& Rock (1989) \\
\hline
\end{tabular}

(1)RED, Band1; NIR, Band2; SWIR, Band5; SWIR 1 , Band6; and SWIR 2 , Band7.

Pesq. agropec. bras., Brasília, v.52, n.11, p.1063-1071, nov. 2017 DOI: 10.1590/S0100-204X2017001100012
Drought induces abnormalities in spectral response and, therefore, data were standardized. In addition, this procedure reduces spatial variation influence in vegetation type and in land cover (Caccamo et al., 2011). The following expression was used for normalization:

$$
\mathrm{Z}_{\mathrm{kxy}}=\left(\mathrm{SI}_{\mathrm{kxy}}-\mu_{\mathrm{kx}}\right) / \sigma_{\mathrm{kx}}
$$

where $Z_{\mathrm{kxy}}$ is the value of $\mathrm{Z}$ for the pure pixel $\mathrm{k}$ during the month $\mathrm{x}$, in the year $\mathrm{y}$; $\mathrm{SI}_{\mathrm{kxy}}$ is the spectral index value for the pure pixel $\mathrm{k}$ during the month $\mathrm{x}$, in the year $y ; \mu_{\mathrm{kx}}$ is the spectral index mean value for the pure pixel $\mathrm{k}$ during the month $\mathrm{x}$, in the $\mathrm{n}$ years studied; and $\sigma_{\mathrm{kx}}$ is the standard deviation of pure pixel $\mathrm{k}$ during the month $x$, in $n$ years (Saleska et al., 2007). The $\mathrm{Z}$ value of each month was calculated for the crop years 2007/08, 2008/09, 2009/10 and 2013/14 (time $\mathrm{n}$ ), in order to obtain the mean values during the crop vegetative stage: germination, tillering, and elongation of stems (Steduto et al., 2012). This vegetative period occurred from October to April, in the selected pure pixels.

The first step in the performed data analysis consisted of detecting the drought seasons, using the SPEI data for the vegetative season, of the crop years 2007/08, 2008/09, 2009/10 and 2013/14. SPEI values calculated monthly, quarterly, and six-monthly were also considered for defining drought severity, taking into account a possible lag between patterns of rainfall and vegetation response (Quiring \& Ganesh, 2010).

The studied period (October to April) was selected because all plots were in the vegetative and in the yield formation stages (Doorenbos \& Kassam, 1979); and elongation of leaves and stalks are much more sensitive than photosynthesis to water stress (Steduto et al., 2012).

The second step in the analysis consisted of the analysis of data (spectral indices and meteorological data) distribution and of establishing the correlation between indices (pure pixels monthly calculated and standardized) and SPEI, throughout the studied period. A Shapiro-Wilk normality test was calculate for spectral indices and meteorological data. As SPEI data were not normal distribution at $5 \%$ probability, the Spearman correlation coefficient was used.

The period with the highest correlation between monthly calculated indices and SPEI data was scrutinized as the last step in the analysis. 


\section{Results and Discussion}

The SPEI (1 month) values calculated for January and February were the ones that effectively distinguished the years considered dry (only 2013/2014, in this work), from those considered normal (2007/08 and 2008/09) or rainy $(2009 / 10)$.

The 2007/08 crop year was considered normal, since SPEI values (1 month) between November and April ranged between 0 and 1 .

The 2008/09 crop year was also considered normal, although it presented a negative (near normal) SPEI (1 month) value in the months of December, February, and March. Intense rainfall events in the months of October to December $(320 \mathrm{~mm})$ were responsible for the characterization of this crop year as normal. As for the 2009/10 crop year, it was considered rainy due to the high SPEI values for 1, 3, and 6 months.

In the crop year of 2013/14, SPEI values (1 month, 3 months or 6 months) were negative from December to February, due to below-average precipitation for the entire period. According to the Annual Disaster Statistical Review of 2014 (Guha-Sapir et al., 2015), the drought occurred in Brazil in 2014 made 27 million victims, placing it fourth in drought events with the greatest human impact since 2004.

SPEI values didn't show spatial variation in the studied area, with the spatial resolution used.

The correlations between SPEI values $(1,3$, and 6 months) and spectral indices are shown in Table 2. All the harvest years (2007/08, 2008/09, 2009/10 and 2013/14) were analyzed jointly in their calculation. The GVMI index (MYD) showed a positive and significant Spearman correlation $(\rho=0.65)$ with SPEI (1 month) in November. This result was probably due to the fact that this index provides quantitative information on the water content in the vegetation and, in the month of November, the precipitation was above that registered by the climate normal, in all the harvest years.

January had the highest frequency of indices with significant correlations with SPEI (1 month), but they were all negative (Table 2). This was because a lower

Table 2. Spearman Correlation between spectral indices and 1, 3, and 6-month SPEI values, calculated for each month, in the four crop years evaluated.

\begin{tabular}{|c|c|c|c|c|c|c|c|c|c|c|c|c|c|c|c|c|}
\hline Month & $\begin{array}{c}\text { NDVI_ } \\
\text { MOD }\end{array}$ & $\begin{array}{l}\text { NDVI } \\
\text { MYD }\end{array}$ & $\begin{array}{l}\text { EVI2 } \\
\text { MOD }\end{array}$ & $\begin{array}{l}\text { EVI2 } \\
\text { MYD }\end{array}$ & $\begin{array}{c}\text { GVMI } \\
\text { MOD }\end{array}$ & $\begin{array}{l}\text { GVMI } \\
\text { MYD }\end{array}$ & $\begin{array}{l}\text { MSI } \\
\text { MOD }\end{array}$ & $\begin{array}{l}\text { MSI } \\
\text { MYD }\end{array}$ & $\begin{array}{l}\text { NDI6 } \\
\text { MOD }\end{array}$ & $\begin{array}{l}\text { NDI6 } \\
\text { MYD }\end{array}$ & $\begin{array}{l}\text { NDI7- } \\
\text { MOD }\end{array}$ & $\begin{array}{l}\text { NDI7- } \\
\text { MYD }\end{array}$ & $\begin{array}{c}\text { NDWI } \\
\text { MOD }\end{array}$ & $\begin{array}{c}\text { NDWI } \\
\text { MYD }\end{array}$ & $\begin{array}{l}\text { SRWI_ } \\
\text { MOD }\end{array}$ & $\begin{array}{l}\text { SRWI_ } \\
\text { MYD }\end{array}$ \\
\hline & \multicolumn{16}{|c|}{ SPEI (1 month) data } \\
\hline Oct. & 0.24 & 0.24 & 0.27 & 0.16 & -0.2 & $-0.46^{*}$ & 0.20 & 0.23 & -0.05 & -0.07 & 0.17 & 0.22 & -0.11 & -0.08 & -0.11 & 0.01 \\
\hline Nov. & -0.09 & -0.12 & -0.03 & 0.07 & $0.39 *$ & $0.65 * *$ & 0.24 & 0.11 & 0.25 & -0.06 & 0.23 & 0.06 & 0.30 & 0.13 & 0.29 & 0.13 \\
\hline Dec. & -0.31 & $-0.39 *$ & -0.19 & -0.45 & 0.19 & -0.06 & -0.23 & -0.17 & -0.11 & -0.12 & -0.23 & -0.14 & -0.07 & -0.10 & -0.04 & -0.13 \\
\hline Jan. & -0.41 & -0.44 & -0.60 & $-0.45^{*}$ & -0.19 & $-0.47 *$ & -0.17 & $-0.56^{* *}$ & -0.22 & $-0.42 *$ & -0.21 & $-0.57 * *$ & $-0.42 *$ & $-0.45^{*}$ & $-0.48^{*}$ & $-0.56^{* *}$ \\
\hline Feb. & 0.04 & -0.14 & 0.05 & -0.28 & -0.32 & 0.06 & -0.05 & -0.22 & -0.16 & -0.14 & -0.07 & -0.18 & -0.23 & -0.19 & -0.21 & $-0.41^{*}$ \\
\hline Mar. & -0.11 & $0.45^{*}$ & 0.06 & $0.38^{*}$ & -0.11 & 0.08 & -0.06 & -0.06 & -0.15 & 0.17 & -0.06 & -0.04 & -0.25 & -0.04 & -0.25 & 0.07 \\
\hline \multirow[t]{2}{*}{ Apr. } & -0.64 & $-0.4^{*}$ & -0.25 & $-0.64 * *$ & -0.1 & $-0.47 *$ & $-0.59^{* *}$ & $-0.52 * *$ & $-0.6 * *$ & -0.33 & $-0.58 * *$ & $-0.52 * *$ & -0.23 & $-0.39^{*}$ & -0.23 & -0.3 \\
\hline & \multicolumn{16}{|c|}{ SPEI (3 months) data } \\
\hline Oct. & 0.24 & 0.24 & 0.27 & 0.16 & -0.16 & $-0.46^{*}$ & 0.20 & 0.23 & -0.05 & -0.07 & 0.17 & 0.22 & -0.11 & -0.08 & -0.11 & 0.01 \\
\hline Nov. & -0.06 & 0.16 & 0.04 & 0.32 & -0.32 & $-0.54 * *$ & -0.03 & 0.07 & -0.21 & 0.01 & -0.04 & 0.13 & -0.26 & -0.07 & -0.25 & 0.0 \\
\hline Dec. & -0.31 & $-0.39 *$ & -0.19 & $-0.46^{*}$ & 0.19 & -0.06 & -0.23 & -0.17 & -0.11 & -0.12 & -0.23 & -0.14 & -0.07 & -0.10 & -0.04 & -0.13 \\
\hline Jan. & -0.31 & $-0.46^{*}$ & $-0.39 *$ & $-0.54 * *$ & -0.03 & -0.17 & -0.12 & $-0.46^{*}$ & -0.13 & -0.25 & -0.15 & $-0.47^{*}$ & -0.17 & -0.36 & -0.25 & $-0.54 * *$ \\
\hline Feb. & 0.05 & 0.20 & 0.0 & 0.06 & -0.17 & 0.21 & -0.07 & -0.01 & -0.16 & -0.12 & -0.09 & 0.04 & -0.02 & -0.07 & 0.0 & -0.28 \\
\hline Mar. & 0.12 & 0.09 & 0.27 & 0.0 & $0.43 *$ & $0.52 * *$ & 0.12 & $0.47^{*}$ & 0.18 & 0.21 & 0.11 & $0.49^{* *}$ & 0.16 & $0.51 * *$ & 0.16 & 0.32 \\
\hline \multirow[t]{2}{*}{ Apr. } & 0.06 & 0.04 & -0.05 & -0.02 & -0.24 & $0.42 *$ & -0.09 & 0.05 & -0.08 & 0.21 & -0.09 & 0.07 & 0.02 & 0.15 & 0.02 & 0.0 \\
\hline & \multicolumn{16}{|c|}{ SPEI (6 months) data } \\
\hline Oct. & 0.28 & $0.38^{*}$ & 0.34 & 0.34 & 0.02 & -0.31 & 0.37 & $0.48 * *$ & -0.03 & 0.29 & 0.32 & $0.46^{*}$ & -0.06 & 0.14 & -0.06 & 0.09 \\
\hline Nov. & -0.04 & 0.24 & 0.09 & $0.392 *$ & -0.22 & -0.15 & 0.10 & 0.11 & -0.13 & 0.09 & 0.08 & 0.15 & -0.13 & 0.0 & -0.13 & -0.06 \\
\hline Dec. & -0.31 & $-0.39 *$ & -0.19 & $-0.46^{*}$ & 0.19 & -0.06 & -0.23 & -0.17 & -0.11 & -0.12 & -0.23 & -0.14 & -0.07 & -0.10 & -0.04 & -0.13 \\
\hline Jan. & $-0.41 *$ & $-0.44^{*}$ & $-0.6^{* *}$ & $-0.45^{*}$ & -0.2 & $-0.47^{*}$ & -0.174 & $-0.56^{* *}$ & -0.22 & $-0.42 *$ & -0.20 & $-0.57 * *$ & $-0.42^{*}$ & $-0.45^{*}$ & $-0.48 *$ & $-0.56^{* *}$ \\
\hline Feb. & 0.05 & 0.20 & 0.0 & 0.06 & -0.17 & 0.21 & -0.07 & -0.01 & -0.16 & -0.12 & -0.09 & 0.04 & -0.02 & -0.07 & 0.0 & -0.28 \\
\hline Mar. & 0.12 & 0.09 & 0.27 & 0.0 & $0.42 *$ & $0.518^{* *}$ & 0.12 & $0.475^{*}$ & 0.18 & 0.21 & 0.11 & $0.49 * *$ & 0.16 & $0.51 * *$ & 0.16 & 0.32 \\
\hline Apr. & 0.02 & -0.02 & 0.16 & 0.09 & 0.22 & 0.17 & -0.17 & -0.02 & -0.13 & -0.01 & -0.17 & 0.0 & 0.20 & 0.16 & 0.20 & 0.08 \\
\hline
\end{tabular}

*and**Significant at 5 and $1 \%$ probability, respectively. 
volume of precipitation may result in lower values of SPEI, when it is calculated for a period with high rainfall volumes (values above the climate normals), as occurred in January, in the 2013/14 harvest. In January, sugarcane was in the vegetative phase, so the plant was in the phenological stage with the greatest sensitivity to the water deficit (FAO, 2015). Those negative correlations, therefore, indicated that the spectral indices did not present the same trend as the SPEI, since this index presented positive values (precipitation above the climate normals). That is, in most harvests, the precipitation volumes in January, although high, were not sufficient to meet the needs of the plants.

In March, positive correlations were observed between the spectral indices NDVI (MYD) and EVI2 (MYD), and SPEI (1 month) (Table 2). The positive values in March for SPEI (1 month) and the spectral indices were due to the higher precipitation in February and March - 204 and $207 \mathrm{~mm}$ in 2007/08; 228 and $168 \mathrm{~mm}$ in 2008/09; and 161 and $123 \mathrm{~mm}$ in 2009/10 -, except for the 2013/14 harvest. Zhang et al. (2013) also observed that on agricultural land, the NDVI is sensitive to precipitation, showing time gap of 16 to 24 days.

In April, the correlations were, again, negatively significant, as the spectral indices had negative values, and the SPEI (1 month) had positive values. In this month, the sugarcane was in the end of productivity formation period, and beginning of the maturation period. Therefore, the lower values of the spectral indices were due to the lower physiological activity in that moth, compared to the previous ones.

Rhee et al. (2010) observed that the spectral response of the agricultural vegetation shows stronger correlations with the long-term dry periods (i.e., SPI of 3 and 6 months). Therefore, for the 1-month period, positive correlations between the spectral indices and the SPEI were not expected. Jain et al. (2010), comparing the NDVI and WSVI (water supply vegetation index) with the SPI values calculated for $1,3,6,9$, and 12 months, observed that the impact of precipitation on vegetation does not occur instantaneously; rather, it is cumulative. In most cases, precipitation that occurs in 1 month does not strongly affect vegetation in that month.
The SPEI calculated for 3 months (Table 2) did not show significant correlations with spectral indexes from October to December. However, in January some spectral indices showed significant negative correlation with SPEI (3 months): NDVI (MYD), EVI 2 (MOD and MYD), MSI (MYD), NDI7 (MYD) and SRWI (MYD). In March, the correlations were positive between SPEI (3 months) and GVMI (MOD and MYD), MSI (MYD), NDI7 (MYD), and NDWI (MYD), with high correlation values, following the Rhee et al. (2010) hypothesis. An explanation for the higher correlation of the Modis Aqua (MYD) satellite spectral indices with the SPEI data may be related to the fact that this satellite captures images (Descalvado) at around 13:00 in the studied area (Descalvado, SP, Brazil). At this hour of the day, the temperature is higher and the sugarcane plants have closed stomata. Consequently, there is less water loss and, therefore, higher reflectance in the medium-infrared region, which are the bands present in the indices: GVMI, MSI, and NDI7.

The correlation between spectral indexes and 6-month SPEI values (Table 2) was negative in January, for most of the spectral indices. This result agrees with the ones for SPEI time intervals of 1 and 3 months. In March, similarly to what was observed for SPEI (3 months), the correlations observed between SPEI (6 months) and the spectral indices GVMI (MOD and MYD), MSI (MYD), NDI7 (MYD), and NDWI (MYD) were significant. According to the literature (Caccamo et al., 2011; Sow et al., 2013), the indices using the bands 2 (near infrared, NIR), and 6 and 7 (infrared-medium, SWIR) have greater potential to identify drought events in vegetation. The same was observed in this study.

The correlations between the spectral indices GVMI (MOD and MYD), MSI (MYD), NDI7 (MYD), and NDWI (MYD) and SPEI (3 and 6 months) values, in March, were significant for all years considered (Figure 1). In March, the indices showed the same trend as SPEI's, except for the NDI7 in 2010, which showed negative values, while SPEI indicated positive values. In 2014, the year that the drought caused great damage to sugarcane crops in Brazil, all spectral indices were negative. This indicates the sensibility of Modis indices in detecting drought in sugarcane, especially in dry years. 

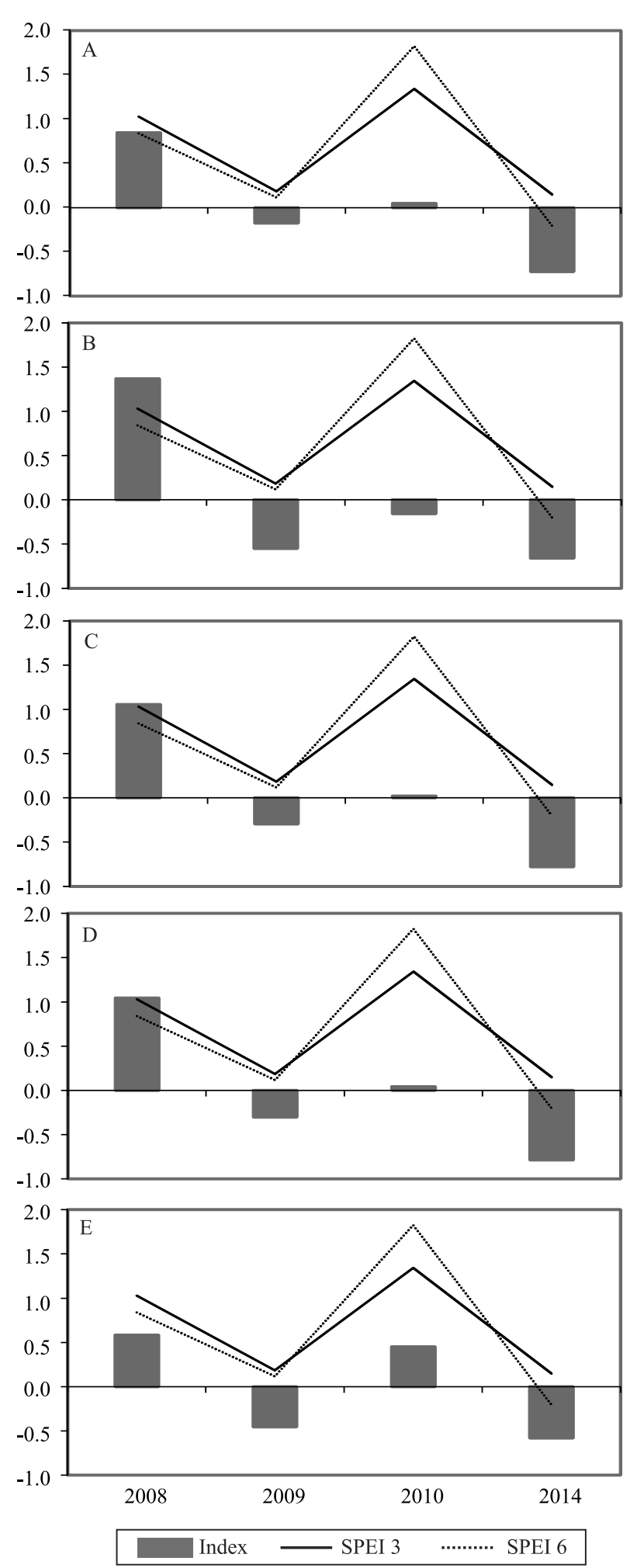

Figure 1. March monthly values for SPEI 3-months and SPEI 6-months with: A, GVMI_MOD; B, GVMI_MYD; C, MSI_MYD; D, NDI7_MYD; and E, NDWI_MYD. Averaged data at all pixels, for the years 2008, 2009, 2010, and 2014.

\section{Conclusions}

1. The Modis sensor is able to detect drought events in sugarcane crops, particularly with Modis data from Aqua satellite.

2. The spectral indices GVMI (MOD and MYD), MSI (MYD), NDI7 (MYD), and NDWI (MYD) are effective in drought detection for sugarcane, showing significant correlations with SPEI data.

3. SPEI analysis with 1, 3, and 6 months have similar trends (drought or not).

4. The absence of spatial variation for the SPEI data, with the resolution available for this study $\left(0.5^{\circ}\right)$, hinders their contrast with the Modis data.

\section{Acknowledgments}

To the Fundação de Amparo à Pesquisa de São Paulo (Fapesp, project No. 2014/17090-5), for financial support.

\section{References}

CACCAMO, G.; CHISHOLM, L.A.; BRADSTOCK, R.A.; PUOTINEN, M.L. Assessing the sensitivity of MODIS to monitor drought in high biomass ecosystems. Remote Sensing of Environment, v.115, p.2626-2639, 2011. DOI: 10.1016/j. rse.2011.05.018.

CECCATO, P.; FLASSE, S.; TARANTOLA, S.; JACQUEMOUD, S.; GRÉGOIRE, J.-M. Detecting vegetation leaf water content using reflectance in the optical domain. Remote Sensing of Environment, v.77, p.22-33, 2001. DOI: 10.1016/S00344257(01)00191-2.

CECCATO, P.; GOBRON, N.; FLASSE, S.; PINTY, B.; TARANTOLA, S. Designing a spectral index to estimate vegetation water content from remote sensing data: Part 1: theoretical approach. Remote Sensing of Environment, v.82, p.188-197, 2002. DOI: 10.1016/S0034-4257(02)00037-8.

CEPAGRI. Centro de Pesquisas Meteorológicas e Climáticas Aplicadas à Agricultura. Clima dos municípios paulistas. Available at: <http://www.cpa.unicamp.br/outras-informacoes/ clima_muni_153.html>. Accessed on: Jan. 232016.

CHEN, F.; SHANG, H.; YUAN, Y. Dry/wet variations in the eastern Tien Shan (China) since AD 1725 based on Schrenk spruce (Picea schrenkiana Fisch. et Mey) tree rings. Dendrochronologia, v.40, p.110-116, 2016. DOI: 10.1016/j.dendro.2016.07.003.

CHUVIECO, E.; RIAÑO, D.; AGUADO, I.; COCERO, D. Estimation of fuel moisture content from multitemporal analysis of Landsat Thematic Mapper reflectance data: applications in fire danger assessment. International Journal of Remote Sensing, v.23, p.2145-2162, 2002. DOI: 10.1080/01431160110069818.

COUMOU, D.; RAHMSTORF, S. A decade of weather extremes. Nature Climate Change, v.2, p.491-496, 2012. DOI: 10.1038/ nclimate1452.

Pesq. agropec. bras., Brasília, v.52, n.11, p.1063-1071, nov. 2017 DOI: $10.1590 / \mathrm{S} 0100-204 X 2017001100012$ 
DOORENBOS, J.; KASSAM, A.H. Yield response to water. Rome: FAO, 1979. 257p. (FAO. Irrigation and Drainage Paper, 33).

EZZINE, H.; BOUZIANE, A.; OUAZAR, D. Seasonal comparisons of meteorological and agricultural drought indices in Morocco using open short time-series data. International Journal of Applied Earth Observation and Geoinformation, v.26, p.36-48, 2014. DOI: 10.1016/j.jag.2013.05.005.

FAO. Food and Agriculture Organization of the United Nations. Crop Water Information: Sugarcane. Available at: $<$ http://www. fao.org/land-water/databases-and-software/crop-information/ sugarcane/en/>. Accessed on: Dec. 122015.

GAO, B.-C. NDWI. A normalized difference water index for remote sensing of vegetation liquid water from space. Remote Sensing of Environment, v.58, p.257-266, 1996. DOI: 10.1016/ S0034-4257(96)00067-3.

GHULAM, A.; QIN, Q.; TEYIP, T.; LI, Z.-L. Modified perpendicular drought index (MPDI): a real-time drought monitoring method. ISPRS Journal of Photogrammetry and Remote Sensing, v.62, p.150-164, 2007. DOI: 10.1016/j. isprsjprs.2007.03.002.

GU, Y.; BROWN, J. F.; VERDIN, J. P.; WARDLOW, B. A fiveyear analysis of MODIS NDVI and NDWI for grassland drought assessment over the central Great Plains of the United States. Geophysical Research Letters, v.34, p.L06407, 2007. DOI: 10.1029/2006GL029127.

GUHA-SAPIR, D.; HOYOIS, P.; BELOW, R. Annual Disaster Statistical Review 2014: the numbers and trends. Brussels: CRED, 2015. 44p.

HAO,Z.; AGHAKOUCHAK, A.; NAKHJIRI, N.;FARAHMAND, A. Global integrated drought monitoring and prediction system. Scientific Data, v.1, p.1-10, 2014. DOI: 10.1038/sdata.2014.1.

HARDISKY, M.A.; KLEMAS, V.; SMART, R.M. The influence of soil salinity, growth form, and leaf moisture on the spectral radiance of Spartina alterniflora canopies. Photogrammetric Engineering \& Remote Sensing, v.49, p.77-83, 1983.

HUNT JR., E.R.; ROCK, B.N. Detection of changes in leaf water content using near and middle-infrared reflectances. Remote Sensing of Environment, v.30, p.43-54, 1989. DOI: 10.1016/00344257(89)90046-1.

IBGE. Instituto Brasileiro de Geografia e Estatística. Sistema IBGE de Recuperação Automática - SIDRA. Produção Agrícola Municipal - PAM. Available at: <http://www.sidra.ibge.gov.br/ bda/pesquisas/pam>. Accessed on: Apr. 2016.

JAIN, S.K.; KESHRI, R.; GOSWAMI, A.; SARKAR, A. Application of meteorological and vegetation indices for evaluation of drought impact: a case study for Rajasthan, India. Natural Hazards, v.54, p.643-656, 2010. DOI: 10.1007/s11069009-9493-x.

JIANG, Z.; HUETE, A.R.; DIDAN, K.; MIURA, T. Development of a two-band enhanced vegetation index without a blue band. Remote Sensing of Environment, v.112, p.3833-3845, 2008. DOI: $10.1016 /$ j.rse.2008.06.006.

LE, M.H.; CORZO PEREZ, G.; SOLOMATINE, D.; NGUYEN, L.B. Meteorological drought forecasting based on climate signals using artificial neural network - a case study in Khanhhoa Province Vietnam. Procedia Engineering, v.154, p.1169-1175, 2016. DOI: 10.1016/j.proeng.2016.07.528.

NASA. National Aeronautics and Space Administration. MODIS: Moderate Resolution Imaging Spectroradiometer: Specifications. Available at: <http://modis.gsfc.nasa.gov/about/specifications. php>. Accessed on: Oct. 72015.

OLDFORD, S.; LEBLON, B.; MACLEAN, D.; FLANNIGAN, $M$. Predicting slow-drying fire weather index fuel moisture codes with NOAA-AVHRR images in Canada's northern boreal forests. International Journal of Remote Sensing, v.27, p.3881-3902, 2006. DOI: 10.1080/01431160600784234.

PACHAURI, R.K.; MEYER, L.A. (Ed.). Climate Change 2014: synthesis report. Geneva: IPCC, 2014. 151p. Contribution of Working Groups I, II and III to the Fifth Assessment Report of the Intergovernmental Panel on Climate Change

QUIRING, S.M.; GANESH, S. Evaluating the utility of the Vegetation Condition Index (VCI) for monitoring meteorological drought in Texas. Agricultural and Forest Meteorology, v.150, p.330-339, 2010. DOI: 10.1016/j.agrformet.2009.11.015.

RHEE, J.; IM, J.; CARBONE, G.J. Monitoring agricultural drought for arid and humid regions using multi-sensor remote sensing data. Remote Sensing of Environment, v.114, p.28752887, 2010. DOI: 10.1016/j.rse.2010.07.005.

SALESKA, S.R.; DIDAN, K.; HUETE, A.R.; ROCHA, H.R. da. Amazon forests green-up during 2005 drought. Science, v.318, p.612, 2007. DOI: 10.1126/science.1146663.

SMITH, D.M.; INMAN-BAMBER, N.G.; THORBURN, P.J. Growth and function of the sugarcane root system. Field Crops Research, v.92, p.169-183, 2005. DOI: 10.1016/j.fcr.2005.01.017.

SOW, M.; MBOW, C.; HÉLY, C.; FENSHOLT, R.; SAMBOU, B. Estimation of herbaceous fuel moisture content using vegetation indices and land surface temperature from MODIS Data. Remote Sensing, v.5, p.2617-2638, 2013. DOI: 10.3390/rs5062617.

STEDUTO, P.; HSIAO, T.C.; FERERES, E.; RAES, D. Crop yield response to water. Rome: FAO, 2012. 500p. (FAO Irrigation and Drainage Paper, 66).

TADESSE, T.; BROWN, J.; HAYES, M.J. A new approach for predicting drought-related vegetation stress: integrating satellite, climate, and biophysical data over the U.S. central plains. ISPRS Journal of Photogrammetry and Remote Sensing, v.59, p.244253, 2005. DOI: 10.1016/j.isprsjprs.2005.02.003.

TUCKER, C.J. Red and photographic infrared linear combinations for monitoring vegetation. Remote Sensing of Environment, v.8, p.127-150, 1979. DOI: 10.1016/0034-4257(79)90013-0.

ÚNICA. União da Indústria de Cana-de-Açúcar. Unicadata. Available at: $<$ http://www.unicadata.com.br $>$. Accessed on: Sept. 52015.

VICENTE-SERRANO， S.M.; BEGUERÍA， S.; LÓPEZMORENO, J.I. A multiscalar drought index sensitive to global warming: the standardized precipitation evapotranspiration index. Journal of Climate, v.23, p.1696-1718, 2010. DOI: 10.1175/2009JCLI2909.1. 
WANG, H.; VICENTE-SERRANO, S.M.; TAO, F.; ZHANG, X.; WANG, P.; ZHANG, C.; CHEN, Y.; ZHU, D.; EL KENAWY, A. Monitoring winter wheat drought threat in Northern China using multiple climate-based drought indices and soil moisture during 2000-2013. Agricultural and Forest Meteorology, v.228-229, p.1-12, 2016. DOI: 10.1016/j.agrformet.2016.06.004.

WANG, R.; ZENG, C.; LI, P.; SHEN, H. Terra MODIS band 5 Stripe noise detection and correction using MAP-based algorithm. In: REMOTE SENSING, ENVIRONMENT AND TRANSPORTATION ENGINEERING, 2011, Nanjing. Proceedings. Nanjing: IEEE, 2011. p.8612-8615. RSETE 2011.

WMO. World Meteorological Organization. Standardized precipitation index: user guide. Switzerland: WMO, 2012. 24p. (WMO, 1090).

ZARCO-TEJADA, P.J.; USTIN, S.L. Modeling canopy water content for carbon estimates from MODIS data at land EOS validation sites. In: IEEE INTERNATIONAL GEOSCIENCE AND REMOTE SENSING SYMPOSIUM, 2001, Sydney. Scanning the present and resolving the future: proceedings. Sydney: IEEE, 2001. v.1, p.342-344. IGARSS 2001. DOI: 10.1109/ IGARSS.2001.976152.

ZHANG, D.; LIANG, Y. A long lasting and extensive drought event over China in 1876-1878. Advances in Climate Change Research, v.1, p.91-99, 2010. DOI: 10.3724/SP.J.1248.2010.00091.

ZHANG, F.; ZHANG, L.-W.; WANG, X.-Z.; HUNG, J.-F. Detecting Agro-Droughts in Southwest of China Using MODIS Satellite Data. Journal of Integrative Agriculture, v.12, p.159168, 2013. DOI: 10.1016/S2095-3119(13)60216-6.

ZHAO, H.; GAO, G.; AN, W.; ZOU, X.; LI, H.; HOU, M. Timescale differences between SC-PDSI and SPEI for drought monitoring in China. Physics and Chemistry of the Earth, p.1-11, 2015. DOI: 10.1016/j.pce.2015.10.022.

$\overline{\text { Received on August 3, } 2016 \text { and accepted on April 20, } 2017}$ 